Jurnal Indonesia Sosial Teknologi: p-ISSN: 2723 - 6609

e-ISSN : 2745-5254

Vol. 2, No. 6 Juni 2021

\title{
STRATEGI MANAJEMEN SUMBER DAYA MANUSIA DALAM MENGELOLA KEPEMIMPINAN MILLENIAL UNTUK MENINGKATKAN PRODUKTIVITAS KARYAWAN YANG DIDUKUNG OLEH TEKNOLOGI MODERN
}

\section{Yeremia Steven Putra Ongkowijoyo}

Universitas Katolik Widya Mandala Surabaya

Email: jerryongkowijoyo@gmail.com

\section{Abstract}

Technology is present in the industrial world as a medium to improve employee performance and productivity. Optimal productivity will help the company to continue to compete with its competitors. To achieve optimal productivity, leaders must be able to demonstrate superior human resource management skills. In the current era, many leaders in the millennial generation have begun to take part in managing HR. The advantages possessed by the millennial generation are that they are close to technology and have higher flexibility than the previous generation. So, companies can optimize millennial leadership in optimizing employee productivity by always providing the latest technology developments. Technology is able to encourage the potential of millennial leaders to manage existing human resources so that employees can reach their maximum potential in giving their best performance.

Keyword: technology; leadership; millennial; human Resources; productivity

\begin{abstract}
Abstrak
Penelitian ini dibuat untuk memberikan analisis literatur mengenai strategi manajemen sumber daya manusia dalam mengelola kepemimpinan milenial untuk meningkatkan produktivitas karyawan dengan dukungan teknologi modern. Metode penelitian ini menggunakan metode studi literatur dimana peneliti mengkaji dan mensintesis berbagai macam referensi ilmiah terkait strategi manajemen sumber daya manusia dalam kepemimpinan milenial untuk mengelola sumber daya manusia dengan dukungan teknologi modern. Hasil dari analisis literatur menunjukkan untuk mencapai produktivitas yang optimal, para pemimpin harus mampu menunjukkan keterampilan mengelola sumber daya manusia secara unggul. Di era saat ini, mulai banyak muncul pemimpin di generasi milenial yang mengambil peran dalam mengelola SDM. Keunggulan yang dimiliki oleh generasi milenial adalah dekat dengan teknologi dan memiliki fleksibilitas yang lebih tinggi daripada generasi yang sebelumnya. Maka, perusahaan dapat mengoptimalkan kepemimpinan milenial dalam mengoptimalkan produktivitas karyawan dengan selalu memberikan perkembangan teknologi terbaru. Teknologi mampu mengoptimalkan potensi pemimpin milenial.
\end{abstract}

Kata kunci: teknologi; kepemimpinan; milenial; sumber daya manusia; produktivitas 


\section{Pendahuluan}

Dunia selalu berubah sepanjang waktu. Perubahan ini terjadi dalam berbagai aspek kehidupan manusia. Menurut (Robbins et al., 2015), manusia memiliki kebutuhan untuk berkembang dan melakukan perubahan di dalam kehidupannya. Berdasarkan pernyataan tersebut, manusia selalu mencari upaya untuk menciptakan sesuatu yang baru. Karya-karya yang dibuat oleh manusia salah satunya adalah perkembangan teknologi. Teknologi sudah menjadi bagian keseharian yang tidak dapat lepas dari kehidupan bermasyarakat.

Menurut (Volti, 2009), teknologi adalah "a system created by humans that uses knowledge and organization to produce objects and techniques for the attainment of specific goals". Examples that currently exist, such as the laser, the television, or the computer, all qualify as technology according to the criteria of this definition". Dari definisi tersebut, teknologi yang ada di sekitar kita dapat berupa laser, televisi, komputer dan hal-hal lain. Teknologi muncul karena ada tujuan yang dibuat oleh manusia. Tujuan paling sederhana adalah agar membuat hidup manusia menjadi lebih mudah dan praktis dengan munculnya teknologi. Menurut Bigelow dalam (Li-Hua, 2009), konsep teknologi memuat beberapa aspek dibawah berikut ini :
a. Physical (process)
b. Methapysicial (principles)
c. Sociocultural (nomenclature)
d. Functional (application of science)
e. Beneficial (considered useful)
f. Purposeful (promoting societalg gain)
g. Economic (emulment)

Manfaat hadirnya teknologi dapat dirasakan dari waktu ke waktu. Misalnya dalam aspek transportasi, pada zaman dahulu manusia menciptakan kereta kuda untuk mobilisisasi. Dari kereta kuda, berkembang menjadi transportasi dengan mesin uap pada revolusi industri yang pertama. Dari transportasi bertenaga mesin uap, berkembang menjadi transportasi udara, darat, dan laut yang digunakan manusia dalam aktivitasnya. Manfaat yang dapat kita peroleh adalah kecepatan waktu dalam berpergian dari suatu tempat dan tempat yang lain. Selain transportasi, masih banyak aspek-aspek lain yang berkembang dan memberi manfaat pada hidup manusia.

Menurut (Kumar et al., 1999) teknologi memuat dua komponen utama. Pertama, komponen fisik yang memuat hal-hal seperti produk, peralatan, blueprints, teknik, dan proses. Kedua, komponen informasi yang berisi manajemen prosedur, pemasaran, produksi quality control, reliabilitas, keterampilan dalam area kerja. Dari kedua komponen tersebut, maka teknologi juga muncul dalam dunia kerja yaitu keterampilan, produksi, pemasaran, manajemen prosedur, dll. Teknologi dalam dunia kerja berkembang untuk menunjang proses kerja yang lebih baik lagi.

Hadirnya teknologi tentu memberikan perubahan bagi perusahaan di dalam dunia kerja. Namun, hal yang tetap menjadi tujuan sebuah perusahaan adalah produktivitas 
Strategi Manajemen Sumber Daya Manusia dalam Mengelola Kepemimpinan Millenial Untuk Meningkatkan Produktivitas Karyawan yang Didukung oleh Teknologi Modern

karyawannya (Masuda et al., 2012). Salah satu cara dalam mencapai tujuan organisasi adalah dengan melakukan kinerja yang baik (Borman et al., 2003). Dengan kedua pernyataan di atas, maka teknologi dapat hadir sebagai alat untuk memaksimalkan potensi kinerja karyawan yang ada. Apalagi di zaman sekarang, teknologi merupakan kunci utama bagi proses bisnis untuk dapat memiliki daya saing yang kuat.

Produktivitas didefinisikan sebagai nilai-nilai yang diberikan oleh karyawan kepada perusahaannya dalam kurun waktu tertentu (Sakurai \& Jex, 2012). Dalam istilah manajemen operasi, (Jacobs et al., 2004) menyebutkan bahwa produktivitas adalah jumlah output per satuan waktu. Artinya, produktivitas adalah sejumlah nilai yang diberikan kepada karyawannya dalam satuan waktu tertentu. Bagaimana seorang karyawan berproses dan memberikan usahanya kepada perusahaan akan menjadi nilai bagi perusahaan tersebut. Nilai ini bisa menjadi nilai positif atau nilai negatif. Jika positif, maka usaha yang dilakukan oleh karyawan tersebut memberikan manfaat/keuntungan bagi perusahaan. Jika negatif, maka usaha tersebut mendatangkan kerugian bagi perusahaan.

Jika perusahaan tidak memiliki karyawan yang produktif, maka keberlangsungan organisasi tersebut akan terancam. Contohnya adalah perusahaan SEARS, sebuah perusahaan ritel yang telah bangkrut. Dilansir dari kompas.com tahun 2018 pada tahun 1945, pendapatan perusahaan ini mencapai 1 Milliar dollar. Angka itu setara dengan 13 Milliar dollar pada tahun 2018. Saalah satu penyebab perusahaan ini bangkrut adalah karyawannya yang tidak produktif dalam perushaaan. Proses bisnis tidak diserahkan kepada ahlinya, tidak memperhatikan kesejahteraan karyawan, dan tidak fokus pada inti bisnis adalah penyebab kegagalan perusahaan ini yang tercatat. Saat itu, upaya restruktisasi yang dilakukan oleh SEARS tidak mampu menjawab hambatan yang mereka hadapi. Maka, SEARS yang dulunya merupakan raja pasar ritel di Amerika Serikat harus menutup ratusan bahkan ribuan dari tokonya. Ini adalah akibat dari karyawan yang tidak produktif dalam perusahaan tersebut.

Sebaliknya, jika perusahaan memiliki karyawan yang produktif, maka perusahaan tersebut akan menjadi perusahaan yang bertahan di tengah banyaknya perkembangan teknologi yang ada. Perusahaan tersebut tidak akan menjadi perusahaan yang statis dan terus berkembang ke arah yang diinginkan. Hasilnya, perusahaan semacam ini akan menjadi perusahaan yang terus berinovasi dan menciptakan hal-hal baru. Keberlangsungan perusahaan semacam ini terjaga karena mereka mempertahankan produktivitas karyawannya.

Salah satu contoh perusahaan yang terus menjaga kinerja karyawannya agar tetap produktif dan memanfaatkan teknologi adalah perusahaan Apple Inc. Apple saat ini adalah perusahaan teknologi terkemuka di dunia asal Amerika Serikat. Produk yang terkenal oleh perusahana ini adalah telfon genggam dengan merk dagang iPhone. Sebelum menjadi perusahaan besar seperti saat ini, Apple merupakan perusahaan yang bergerak di bidang manufaktur komputer. Setelah sukses di dalam bisnis komputer, Steve Jobs sebagai salah satu pendiri perusahaan tersebut membuat lini-lini produk baru. Salah 
satunya adalah mengeluarkan telpon genggam untuk pertama kalinya dan menciptakan iPod. Saat iPod pertama diluncurkan, pada tahun 2001 penjualannya mencapai 38 juta dollar. Namun tidak berhenti sampai disana, berbagai model iPod terbaru terus bermunculan. Hingga pada tahun 2008, penjualan iPod mencapai 4 milliar dollar. Hal ini tentu menggambarkan produktivitas karyawan di Apple dalam mengembangakan produk barunya. Jika produktivitas ini tidak dilakukan dengan konsisten, maka kemungkinan penjualan produk iPod tidak akan mencapai angka yang setinggi itu.

Dari kasus di atas, dapat disimpulkan bahwa produktivitas karyawan penting untuk mempertahankan keberlangsungan dari sebuah perusahaan. Dalam mengelola produktivitas karyawan ada beberapa hal yang menjadi faktor utama. Salah satu pihak yang mengelola produktivitas karyawan adalah seorang pemimpin. Menurut (Winston \& Patterson, 2006) kepemimpinan (leadership) adalah “... one or more people who selects, equips, trains, and influences one or more follower(s) who have diverse gifts, abilities, and skills and focuses the follower(s) to the organization's mission and objectives causing the follower(s) to willingly and enthusiastically expend spiritual, emotional, and physical energy in a concerted coordinated effort to achieve the organizational mission and objectives". Dari pengertian di atas, dapat disimpulkan bahwa seorang pemimpin adalah orang yang mengatur, mengelola, dan mempengaruhi satu atau lebih orang lain yang beragam untuk memenuhi tujuan dari sebuah organisasi.

Dalam mengelola produktivitas, pemimpin memiliki tugas untuk mengatur agar tiap orang yang berada di bawah koordinasinya dapat menunjukkan produktivitas yang diharapkan. Terlepas dari gaya kepemimpinan apa yang dipakai oleh pemimpin tersebut, produktivitas karyawan tetap menjadi hal utama yang harus dikelola. Fungsi utama kepemimpinan adalah membuat sebuah tim mencapai sebuah tujuan yang sama. Maka dari itu, pemimpin harus memiliki berbagai macam keterampilan yang berguna. Keterampilan yang dimaksud diantaranya adalah pengambilan keputusan, berfikit kritis, sabar, tegas, jujur, dan berkomitmen. Dengan adanya sikap tersebut, maka seorang pemimpin mampu membawa timnya menuju hal yang lebih baik.

Seorang diangkat menjadi pemimpin jika ia dianggap memiliki kemampuan yang memenuhi kebutuhan sesuai perusahaannya masing-masing. Pemimpin di zaman sekarang terdiri dari berbagai macam generasi. Generasi yang cukup menjadi perhatian saat ini adalah generasi millenial. Generasi millenial, menurut (Peña-Solórzano et al., 2019) adalah mereka yang lahir di antara tahun 1981 - 1996. Namun, masih banyak perdebatan antara batasan tahun lahir untuk menentukan kategori generasi millenial. Tahun tersebut adalah tahun umum yang dipakai oleh banyak peneliti untuk menentukan batas tahun lahir. Dalam penelitian ini, penulis tertarik untuk memfokuskan kepemimpinan pada teori kepemimpinan positif. Alasannya dikarenakan teori kepemimpinn positif memiliki komponen yang dekat dengan karakteristik generasi millenial yang ada.

Kepemimpinan positif berorientasi pada perubahan performa ke arah yang lebih baik, melahirkan fokus pada kebajikan, dan menciptakan manusia dalam kondisinya yang paling optimal (Cameron \& Spreitzer, 2011). Fokusnya adalah untuk menyatukan orang- 
Strategi Manajemen Sumber Daya Manusia dalam Mengelola Kepemimpinan Millenial Untuk Meningkatkan Produktivitas Karyawan yang Didukung oleh Teknologi Modern

orang dan memberdayakan mereka agar dapat menciptakan suatu nilai yang bermakna dalam kehidupan mereka. Nilai bermakna yang dimaksud adalah sesuatu yang menjadi kekuatan dan membangun kapasitas dari seseorang (Youssef-Morgan \& Luthans, 2013).

Kepemimpinan positif tidak hanya untuk menciptakan emosi positif bagi orangorang, atau untuk menolong orang agar merasa bahagia. Lebih dari itu, positive leadership berguna untuk memberi pengaruh yang sangat signifikan dan semakin kuat dalam psikologi industri dan organisasi. Hal ini karena performa organisasi. Kondisi zaman sekarang yang jelas berbeda dengan 10 tahun lalu membuat posisi positive leadership menekankan pada apa yang mengangkat seseorang/kelompok, sesuatu yang berjaan dengan benar, serta pengalaman apa yang sangat menarik dan menhginspirasi bagi individu maupun kelompok (Cameron \& Spreitzer, 2011). Kepemimpinan positif membuat suasana kerja menjadi sehat dan bahagia (Snyder \& Lopez, 2001). Dengan suasana kerja yang sehat dan kondusif, performas organisasi tentu akan meningkat ke arah yang lebih baik.

Generasi Millenial memiliki ciri-ciri unik yang berbeda dari generasi yang lain. Generasi Millenial lahir dan tumbuh di era teknologi. Maka salah satu ciri utama generasi ini adalah sangat mampu beradaptasi dan familiar dengan perkembangan teknologi yang ada. Ciri-ciri lainnya adalah mereka dihadapkan pada dunia yang sedang berkembang. Mereka melihat ruang dan waktu semakin menyempit, mereka senang mengeskpos diri mereka dalam media digital. Mereka memiliki ketertarikan untuk berbagi aktivitas yang mereka jalankan ke dunia digital sehingga rekan-rekan mereka mengetahui secara aktual apa yang mereka lakukan saat ni. Selain itu, mereka sangat suka belajar menjadi orang yang multitasking, dimana banyak pekerjaan dilakukan dalam satu waktu. Dengan bantuan perkembangan teknologi yang ada, mereka belajar melakukan berbagai macam hal dalam satu waktu yang sama.

Saat ini, jumlah generasi millenial di dunia mencapai hampir setengah dari seluruh populasi di dunia. Jumlah ini terus akan berkembang setiap tahunnya. Sejumlah penelitian memprediksi bahwa di tahun 2020 ini jumlah millenial di dalam dunia kerja akan mencapai separuh dari seluruh populasi angkatan kerja. Di Indonesia sendiri, tahun 2017 , Kementerian Pemberdayaan Perempuan dan Perlindungan anak mencatat bahwa 33,75\% populasi Indonesia adalah generasi millenial. Dengan demikian, generasi millenial ini akan menjadi generasi yang meggerakkan dunia di masa mendatang.

Dengan ciri-ciri yang dinamis dan adaptif yang dimiliki oleh para generasi millenial, maka beberapa diantara mereka dianggap mampu untuk menjadi seorang pemimpin. Di tempat bekerja penulis, yaitu sebuah perusahaan di Sidoarjo, Jawa Timur, dengan jumlah lebih dari 4400 karyawan, 72\% karyawannya adalah generasi millenial. Dari jumlah tersebut, $62 \%$ adalah millenial dengan jabatan sebagai seorang pemimpin dengan tingkat minimal di level supervisor. Ini artinya cukup banyak millenial yang mulai mengembangkan sisi kepemimpinannya di dalam dunia kerja itu sendiri.

Generasi millenial memiliki gaya tersendiri dalam mengelola tim yang dipimpinnya. Menurut (Novitria, 2020), “Millennials have never known a world without 
instant access to the World Wide Web that can give them answers to their burning questions". Artinya, millenial adalah generasi yang suka mencari tahu segala hal dengan instan/cepat. Ini memunculkan gaya tersendiri dalam memimpin yaitu tentang kecepatan dan efektivitas dalam bekerja. Millenial tidak terlalu memikirkan proses yang begitu rumit, mereka mencari tau dengan teknologi apa mereka mampu memperoleh sebuah cara yang lebih praktis dan cepat.

Gaya unik lainnya dalam pemimpin di usia millenial adalah kepemimpinan yang fleksibel. Generasi ini tidak menyukai sesuatu yang bersifat birokratis dan struktural. Mereka berpandangan bahwa antara atasan dan bawahan harus memiliki kesetaraan dalam berkomunikasi dan tidak dibatasi oleh struktur yang mengikat. Misalnya saja pendiri perusahaan Spotify, Daniel Ek, membuat struktur perusahaannya berdasarkan prinsip fleksibilitas. Bagi dia, struktur organisasi yang terlalu ketat akan membatasi kretivitas dan pengembangan mereka di tempat kerja

Generasi millenial memiliki tantangannya tersendiri dengan kondisi masa depan yang akan diprediksikan. Pertanyaan yang muncul adalah "Apakah pemimpin millenial hari ini akan menjadi pemimpin yang hebat di masa mendatang?". Selain dipaparkan tentang uniknya generasi millenial, perlu diingat bahwa tujuan dari pemimpin adalah mengelola karyawannya agar bisa terus berproduktivitas. Namun, karyawan yang dipimpin atau berelasi dengan pemimpin di usia millenial tidak hanya sebatas di usia yang sama. Beragamnya usia di tempat kerja ini membuat fenomena generation gap. Sebut saja generasi baby boomers yang masih belum terbiasa dengan penggunaan teknologi yang biasa oleh dipakai oleh parah millenial. Bagaimana mengatasi situasi seperti ini?.

Generation gap adalah perbedaan pandangan dan prinsip dalam komunikasi yang dilakukan antar generasi. Perbedaan ini berpotensi menimbulkan konflik antar generasi di tempat kerja. Generation gap terjadi pada millenial sebagai pemimpin maupun memiliki pemimpin yang berbeda generasi dengannya. Dalam hal ini, kita akan berfokus pada millenial sebagai pemimpin dan menghadapi generation gap di dalamnya. Millenial harus mampu mengembangkan kompetensinya sebagai pemimpin agar bisa memahami karakteristik di antar generasi ini.

Untuk mengatasi generation gap, proses kepemimpinan millenial harus bersinergi dengan pengelolaan manajemen sumber daya manusia di tempat kerja. Hal yang nyata terjadi adalah perusahaan masih berusaha menciptakan tempat kerjanya agar memfasilitasi kebutuhan pemimpin millenial yang ada. Peran manajemen sumber daya manusia ini berakar pada 7 employee lifecycle touch point yang dimiliki oleh karyawan. Seven lifecycle touch point tersebut adalah atract, recruit, onboard, development, compensation \& benefit, career development and farewell dan alumni. Dalam setiap titik tersebut, pengelolaan manajemen sumber daya manusia kepada pemimpin millenial harus dikelola dengan semaksimal mungkin. Harapannya, dari 7 employee lifecyvle touch point tersebut, pemimpin millenial mampu memberikan employee experience yang baik kepada karyawannya mulai dari masuk kerja hingga keluar dari pekerjaannya.

Para generasi millenial sekarang sudah mulai mengambil alih peran kepemimpinan khususnya di tempat kerja. Namun, berdasarkan penelitian oleh 
Strategi Manajemen Sumber Daya Manusia dalam Mengelola Kepemimpinan Millenial Untuk Meningkatkan Produktivitas Karyawan yang Didukung oleh Teknologi Modern

(McCleskey, 2018) mengungkapkan bahwa kepemimpinan millenial berfokus kepada "Shared Leadership". Shared Leadership adalah kekuatan tim yang muncul dari pengaruh kepemimpinan kepada beberapa anggota tim (Carson et al., 2007). Melalui definisi ini, kepemimpinan tipe ini merupakan kepemimpinan yang menghindari monopoli kekuasaan dan tanggung jawab tunggal, namun menekankan pada pemahaman dan sistem secara kolektif sebagai sebuah proses sosial dalam memimpin sebuah kelompok. Dalam Shared Leadership, pemimpin memiliki karakteristik yaitu dynamic, simultaneuous, dan on-goin. Dynamic adalah pemimpin yang mampu beradaptasi dengan berbagai perubahan kondisi dan situasi eksternal. Simultaneous yaitu bagaimana pemimpin bersama dengan rekannya mempengaruhi anggota lain untuk mencapai tujuan tim. On-going berarti pemimpin bersikap fleksibel namun tetap memperhatikan kualitas kerja yang optimal.

Menurut (Schuler et al., 1993), menyatakan bahwa "human resources management (HRM) is the recognition of the importance of an organization's workforce as vital human resources contributing to the goals of the organization, and the utilization of several functions and activities to ensure that they are used effectively and fairly for the benefit of the individual the organization, and society." Pernyataan tersebut menyatakan bahwa manajemen sumber daya manusia memberikan pengakuan tentang pentingnya tenaga kerja organisasi sebagai sumber daya manusia utama yang memberi kontribusi bagi pencapaian tujuan-tujuan organisasi serta memberikan kepastian bahwa pelaksanaan fungsi dan kegiatan organisasi dilaksanakan secara efektif dan adil bagi kepentingan individu, organisasi, dan masyarakat.

Pentingnya peran SDM dalam pelaksanaan dan pencapaian tujuan organisasi maka pengelolaan sumber daya manusia harus memperhatikan beberapa aspek seperti aspek staffing, pelatihan dan pengembangan, motivasi dan pemeliharaannya. Secara lebih mendetail dikemukakan oleh (De Cenzo \& Robbins, 1996), menyatakan bahwa: "human resources management is the part of the organization that is concerned with the "people" or human resources aspect of management position, including recruiting, screening, training, rewarding, and appraising".

Dalam manajemen sumber daya manusia, manusia dipandang sebagai asset paling berharga dalam sebuah perusahaan. Hal ini dikarenakan sistem maupun peralatan yang tersedia tidak akan bisa dijalankan tanpa kehadiran manusia. (Tedja, 2020) menyatakan bahwa manusia adalah inti dari segala sistem yang ada di sebuah perusahaan sehingag harus menjadi perhatian utama sebelum menjalankan proes bisnis. Semakin berkembangnya zaman, dunia sumber daya manusia juga semakin berubah. Hadirnya teknologi memberikan warna baru dalam mengelola sumber daya manusia.

Saat ini, praktek sumber daya manusia masih berfokus pada kepemimpinan secara umum. Para pemimpin yang berada di generasi milenial membutuhkan aplikasi praktis dalam menjalankan kepemimpinan. Studi yang dilakukan oleh (Silva et al., 2020) menunjukkan bahwa pemimpim milenial memiliki potensi yang besar namun membutuhkan dukungan perusahaan untuk menciptakan praktek yang jelas dan kriteria 
yang tepat untuk setiap tindakan yang mereka lakukan. Hasil ini selaras dengan studi yang dilakukan oleh (Grotkamp et al., n.d.) yang menunjukkan bahwa pemimpin milenial memerlukan dukungan untuk mengetahui bagaimana memaksimalkan potensinya di dalam perusahan. Dari kedua penelitian ini, maka bisa dilihat bahwa perlu ada pengembangan manajemen sumber daya manusia untuk memaksimalkan kepemimpinan milenial ini.

Pentingnya kepemimpinan di milenial harus menjadi perhatian karena generasi kerja terbesar sekarang berada di usia milenial (Suyanto et al., 2019). Jika pemimpin ini tidak dikelola dengan tepat, maka perusahaan akan mengalami kerugian. Padahal banyak potensi besar yang dimiliki oleh pemimpin generasi milenial. Studi yang dilakukan oleh (WANASIDA et al., 2021) menunjukkan bahwa kepemimpinan milenial memiliki hubungan positif dengan organization agility dan kapasita memanfaatkan teknolgi informasi. Lebih lanjut, studi ini menjelaskan bahwa organization agility dan kapasitas untuk memanfaatkan teknologi informasi memiliki hubungan positif dengan performa organisasi. Sehingga, kepemimpinan milenial jika dikelola dengan tepat akan mendukung organiasi mencapai performa yang lebih baik.

Dengan pengelolaan sumber daya manusia yang tepat, diharapkan karyawan di dalamnya mampu bekerja dengan baik. Banyak sekali strategi yang disarankan atau dimunculkan. Namun, untuk memilih strategi yang tepat diperlukan analisis yang mendalam. Maka dari itu, peneliti akan mencoba menganalisis tentang strategi apa yang tepat yang dapat dilakukan oleh manajemen sumber daya manusia untuk mengoptimalkan proses kepemimpinan millenial dengan memanfaatkan teknologi modern agar memaksimalkan produktivitas karyawan di sebuah perusahaan. Diharapkan, tulisan ini dapat memberikan analisis yang bermanfaat dan saran tentang peran / strategi manajemen sumber manusia yang tepat dalam memaksimal era proses kepemimpinan millenial untuk meningkatkan produktivitas kerja karyawan yang berdasarkan pada teknologi modern.

Secara teoritis, tulisan ini dapat memberikan sumbangsih terhadap pengetahuan, khsusnya psikologi industri organisasi dan manajemen sumber daya manusia tentang peran / strategi manajemen sumber manusia yang tepat dalam memaksimal era proses kepemimpinan millenial untuk meningkatkan produktivitas kerja karyawan yang berdasarkan pada teknologi modern. Secara praktis, bagi para pemimpin di usia millenial, tulisan ini dapat memberikan pandangan baru mengenai strategi MSDM yang harus dibangun untuk membuat karyawan menjadi produktif dalam memanfaatkan teknologi. Bagi jajaran manajemen perusahaan, penelitian ini dapat menjadi referensi bagaimana membentuk strategi pengelolaan SDM di perusahaan yang memiliki pemimpin di usia millenial. Terakhir, bagi peneliti selanjutnya dapat digunakan sebagai acuan referensi dalam membuat analisis literatur tentang peran / strategi manajemen sumber manusia yang tepat dalam memaksimal era proses kepemimpinan millenial untuk meningkatkan produktivitas kerja karyawan yang berdasarkan pada teknologi modern. 
Strategi Manajemen Sumber Daya Manusia dalam Mengelola Kepemimpinan Millenial

Untuk Meningkatkan Produktivitas Karyawan yang Didukung oleh Teknologi Modern

\section{Metode Penelitian}

Metodologi pembahasan yang dipakai adalah studi literatur yang tertera dari berbagai macam referensi dan jurnal. Metode studi literatur adalah aktivitas yang terkait dengan proses pengumpulan data-data pustaka dengan cara membaca, mencatat, serta mengelola data pustaka tersebut sebagai bahan penelitian (Zed, 2004). Jadi, peneliti mencari sumber dari berbagai macam referensi ilmiah untuk dianalisis dan disintesis di dalam tulisan ini. Studi literatur dalam tulisan ini yang menghasilkan beberapa poin pembahasan diantaranya:

a. Kepemimpinan millenial dan pengembangan teknologi

b. Kepemimpinan millenial dalam meningkatkan produktivitas karyawan berdasarkan teknologi

c. Peran dan fungsi MSDM dalam mengelola pemimpin millenial

\section{Hasil dan Pembahasan}

\section{A. Kepemimpinan Millenial dan Pengembangan Teknologi}

Salah satu ciri-ciri generasi millenial adalah adaptif dan tergantung pada teknologi yang berkembang saat ini (Prasarti \& Prakoso, 2020). Dalam hal ini, generasi millenial memanfaatkan perkembangan teknologi untuk menciptakan sesuatu yang bermanfaat bagi diri mereka dan lingkungan. Sifat mereka yang sangat adaptif dengan teknologi memicu kreativitas dalam penggunaannya. Hasilnya, banyak inovasi-inovasi baru yang didasarkan pada teknologi dalam berbagai macam aspek. Studi yang dilakukan oleh ( $\underline{\mathrm{Au}-}$ Yong-Oliveira et al., 2018) menunjukkan bahwa teknologi berhasil mempengaruhi generasi milenial dalam cara mereka memimpin dan bagaimana harapan mereka terhadap pemimpin yang ada.

Perkembangan teknologi juga dimanfaatkan oleh para generasi millenial yang menjadi pemimpin di tempat kerjanya. Salah satu hal paling sederhana adalah bentuk komunikasi yang dilakukan. Saat ini, komunikasi banyak dilakukan dalam bentuk digital. Menurut (Suyanto et al., 2019) pemimpin di generasi milenial sudah erat dengan teknologi komunikasi akibat revolusi industri 4.0. Misalnya ketika ingin mengadakan rapat, dengan perkembangan teknologi saat ini, rapat dapat dilakukan jarak jauh dengan menggunakan video conference. Selain itu, untuk memonitor kinerja timnya sudah tersedia berbagai platform secara online.

Ciri generasi millenial yang lain adalah mereka memiliki rasa percaya diri yang tinggi (Prasarti \& Prakoso, 2020). Rasa percaya diri ini muncul dari sikap optimis yang mereka miliki. Hal ini bisa menjadi modal yang penting bagi sebuah perusahaan. Rasa optimis mendukung pencarian solusi yang lebih cepat atas sebuah permasalahan. Jika ada masalah datang, mereka akan memikir solusi yang praktis dan efektif untuk menyelesaikan masalah tersebut. Mereka mampu memanfaatkan teknologi yang ada untuk memberikan usulan solusi. Misalnya, ketika ada masalah berkaitan dengan proses rekrutmen dalam sebuah perusahaan, generasi millenial mampu mengusulkan untuk membuat rekrutmen secara online. Rekrutmen secara online mampu memangkas waktu 
dan mendukung efisiensi. Memang, mereka masih butuh arahan agar rasa kepercayaan diri mereka tidak bergerak di arah yang salah. Jika mereka dibiarkan seorang diri, mereka mungkin masih kurang menguasai situasi dan terburu-buru dalam mengambil sebuah keputusan. Arahan yang tepat mampu membuat pemimpin millenial menjadi pemimpin yang ideal bagi perusahaan.

Hadirnya teknologi juga mengubah suasana dan budaya dalam sebuah perusahaan. Teknologi tidak serta merta hadir dalam bentuk perangkat berat. Ide-ide baru dalam pikiran manusia itu juga merupakan bentuk teknologi yaitu methaphysical. Pikiran manusia yang baru ini mampu mendorong sebuah perubahan dalam perusahaan. Para pemimpin millenial sangat suka memikirkan ide-ide baru yang sesuai degan keunikan mereka tersendiri. Hal ini terjadi karena mereka adalah generasi yang kreatif, dibesarkan dalam lingkungan yang beragam sehingga mereka memiliki pandangan yang luas terhadap sebuah hal. Dengan pemikiran mereka yang unik dan kreatif, mereka bisa mendorong budaya perubahan dan membuat suasana kerja menjadi lebih kondusif daripada sebelumnya. Jadi, teknologi bisa muncul dalam bentuk pikiran-pikiran kreatif dari para pemimpin millenial.

Dengan perkembangan teknologi yang kian meluas, para pemimpin millenial mulai meninggalkan cara-cara konvensional dalam melakukan sesuatu. Namun, perlu diperhatikan bagi para pemimpin millenial bahwa tidak semua orang terbiasa dengan menggunakan teknologi. Dalam sebuah lingkungan kerja, generasi yang ada di dalamnya tidak hanya generasi millenial saja. Maka dari itu, mereka perlu belajar untuk berkomunikasi dengan generasi yang ada di atas maupun di bawah mereka. Tujuannya adalah agar mereka mampu mengkomunikasikan apa yang ada di pikiran mereka secara baik dan dapat diterima. Perlu diakui bahwa terkadang generasi millenial kurang memahami bagaimana berkomunikasi secara profesional kepada generasi di atasnya. Maka dari itu mereka mengalami kesulitan dalam memberikan ide-ide yang berkaitan tentang teknologi. Maka dari itu, diperlukan bimbingan dan arahan yang tepat bagi generasi ini.

Teknologi juga menghadirkan isu baru yaitu tentang etika dalam dunia maya. Analisis dari (PWC, 2016) menunjukkan bahwa tingkat digitalisasi dari perusahaan juga semakin meningkat dari tahun ke tahun. Diperkirakan, tingkat digitalisasi perusahaan akan mencapai $72 \%$ pada tahun 2025 mendatang. Hadirnya teknologi yang dipakai generasi millenial erat kaitannya dengan etika dan norma yang berlaku dalam perilaku maya. Para pemimpin millenial perlu menyadari bagaimana etika yang harus dimiliki dalam menggunakan media online di dalam tempat kerja. Hal ini penting untuk menghindari konflik dan kesalahpahaman dalam alur informasi yang berjalan. (Saputra et al., 2019) menyatakan bahwa pengambilan dan pengolahan data / informasi harus disertai dengan sikap yang benar untuk menjamin keaslian dan keotentikan data / informasi tersebut Contoh sederhana adalah etika penulisan surat elektronik dan penggunaan media sosial. Dalam menulis surat elektronik, perlu diperhatikan keamanan data dan tata bahasa kepada siapa kita mengirimkan surat tersebut. Dalam penggunaan 
Strategi Manajemen Sumber Daya Manusia dalam Mengelola Kepemimpinan Millenial

Untuk Meningkatkan Produktivitas Karyawan yang Didukung oleh Teknologi Modern

media sosial untuk keperluan company branding, perlu diperhatikan konten apa yang tidak melanggar norma sosial budaya yang ada di masyarakat.

\section{B. Kepemimpinan millenial dalam meningkatkan produktivitas karyawan berdasarkan teknologi}

Teknologi hadir untuk memberikan sebuah tujuan dalam kehidupan manusia. Tujuan tersebut berupa kemudahan, keefektifan, dan penyederhanaan sehingga membuat manusia lebih mudah melakukan sesuatu (Al-Saqqa et al., 2014). Akhirnya, teknologi ini dipakai menjadi dasar dalam melakukan sebuah pekerjaan. Dalam konteks bekerja, teknologi muncul untuk meningkatkan produktivitas. Misalnya dalam revolusi industri pertama di Perancis, dimana mesin uap pertama kali ditemukan untuk kegiatan produksi (Rojko, 2017). Seluruh tenaga kerja manusia dialihkan ke mesin uap tersebut. Alasannya saat itu mesin uap mampu menghasilkan produk yang lebih banyak daripada dikerjakan oleh manusia. Contoh sederhana ini menunjukkan bahwa teknologi hadir untuk meningkatkan produktivitas karyawan di perusahaan.

Penggunaan teknologi untuk meningkatkan produktivitas masih terus berlanjut hingga saat ini. Produktivitas yang disasar juga tidak sebatas produktivitas dalam konteks operasional. Namun produktivitas sudah bergeser ke seluruh tingkat dan jabatan karyawan. Artinya, seluruh karyawan diberikan teknologi untuk memudahkan mereka dalam melakukan pekerjaan mereka. Misalnya, seorang petugas administrasi yang dulunya menggunakan mesin ketik diganti menggunakan komputer untuk mempercepat tugasnya atau seorang teknisi yang diberikan alat-alat teknik terbaru untuk memudahkannya dalam memperbaiki mesin. Jadi, produktivitas sudah didasarkan pada teknologi untuk seluruh karyawan dalam sebuah perusahaan.

Dengan perkembangan teknologi yang begitu masif, generasi millenial menjadi generasi yang paling dekat dengan perkembangan ini. Mereka sangat adaptif terhadap perkembangan, perubahan, maupun penggunaan sebuah teknologi yang ada. Artinya, mereka akan semaksimal mungkin memanfaatkan teknologi yang ada untuk menunjang produktivitas dalam perusahaan.

Kepemimpinan millenial dekat dengan kepemimpinan positive leadership. Dalam kepemimpinan ini, tugas yang diberikan tidak hanya diharapkan untuk diselesiakan dengan biasa saja, namun melebihi standar dan harapan. Millenial sangat suka memberikan usaha yang lebih melalui kreativitasnya. Studi yang dilakukan oleh Do, (Do et al., 2018) menunjukkan bahwa pemimpin milenial mampu menunjukkan sikap yang positif dalam memimpin dan memanfaatkan perkembangan tekbologi yang ada. Maka, teknologi mampu memfasilitasi kebutuhan millenial ini. Hasil yang luar biasa berarti meningkatkan kinerja dan produktivitas dari seorang karyawan. Pemimpin millenial akan melihat sisi kekuatan dari seorang karyawan dalam bekerja. Dengan kelebihan yang dimiliki oleh karyawannya, pemimpin millenial memberikan sebuah tugas yang sesuai. Harapannya karyawan tersebut mampu menyelesaikan tugasnya dengan sebaik-baiknya. Dalam memberikan tugas, pemimpin millenial menyertakan unsur-unsur teknologi di 
dalamnya. Unsur teknologi ini dimasukkan agar karyawan tersebut lebih mudah dan lebih produktif dalam menyelesaikan tugas-tugasnya.

Contoh hadirnya teknologi untuk meningkatkan produktivitas adalah hadirnya reporting secara online dalam sebuah platform performance management. Saat ini, banyak pihak yang mengembangkan pelaporan proses kerja secara online. Melalui teknologi ini, pemimpin millenial dapat mendelegasikan tugas secara lebih terperinci dan detail. Pemimpin millenial juga mampu melihat sejauh apa hasil kerja karyawan tersebut. Jika hasilnya baik maka pemimpin bisa memberikan tugas-tugas tambahan untuk meningkatkan potensi karyawan tersebut. Jika hasilnya belum sesuai dengan harapan, maka pemimpin millenial mampu memberikan feedback. Salah satu ciri milenial adalah bekerja dalam tim. Artinya, mereka mampu melihat kelemahan dan kekurangan timnya dan bisa bersosialisasi dengan pihak yang lebih beragam. Dengan munculnya teknologi seperti ini, pemimpin millenial mampu memaksimalkan potensinya untuk mengelola karyawan yang ada di bawahnya.

Hal lain yang menjadi tantangan adalah komitmen pada generasi millenial untuk mau mengembangkan produktivitas timnya. Teknologi hanyalah sebatas alat jika tidak digunakan dengan tepat. Salah satu kelemahan generasi millenial adalah membangun komitmen. Padahal, komitmen adalah pondasi penting dalam menjadi seorang pemimpin. Generasi millenial perlu diberikan bimbingan dan arahan dalam membangun komitmennya untuk mengelola sebuah tim. Komitmen generasi millenial dapat turun ketika terjadi perselisihan pendapat atau karena mereka merasa bosan dengan apa yang mereka kerjakan. Akhirnya, fungsi monitor sebagai pemimpin mulai menurun dan membuat tim yang dipimpinnya tidak produktif. Hal ini harus dicegah dan segera diatasi bila terjadi.

\section{Peran dan fungsi MSDM dalam mengelola pemimpin millenial}

Fungsi manajemen sumber daya manusia adalah untuk pengelolaan sumber daya manusia harus memperhatikan beberapa aspek seperti aspek staffing, pelatihan dan pengembangan, motivasi dan pemeliharaannya (Cherif, 2020). Dalam konteks pemimpin millenial, fungsi MSDM jatuh kepada pimpinan manajemen diatasnya. Bagaimana manajemen mengarahkan dan memberikan saran kepada para pemimpin millenial menjadi penting. Hal ini dilakukan agar para pemimpin millenial tidak hilang arah dalam melaksanakan tugasnya sebagai pemimpin. Selain itu, para pemimpin millenial juga perlu memahami situasi dan kondisi di masing-masing perusahaan. Dengan pemahaman yang baik, pemimpin millenial mampu menjalankan peran MSDM secara tepat.

Dalm aspek staffing, manajemen harus memberikan gambaran yang tepat bagaimana metode-metode perekrutan karyawan yang sesuai dengan karakteristik millenial namun tetap berorientasi pada kebutuhan tenaga kerja perusahaan. Dengan demikian, manajemen perlu membuat sebuah sistem perekrutan yang lebih modern. Salah satunya adalah dengan memberikan unsur teknologi di dalamnya. Penelitian yang dilakukan oleh (Oswal et al., 2020) menunjukkan bahwa proses rekrutmen harus disertai perkembangan teknologi seperti artificial intelligence atau application tracking system. 
Dengan menggunakan unsur teknologi, selain lebih dekat dengan millenial, perusahaan dapat memperoleh manfaat yang lebih atas hadirnya teknologi ini. Proses perekrutan dapat berjalan lebih ringkas namun tetap sesuai dengan kebutuhan perusahaan. Selain dalam proses rekrutmen, manajemen juga mampu menerapkan proses assesmen kandidat secara lebih efektif untuk mendapatkan profil kandidat yang tepat dan aktual.

Dalam aspek pelatihan dan pengembangan, manajemen dapat mengembangkan modul-modul pembelajaran yang dapat dimanfaatkan. Sistem modul pembelajaran dapat memanfaatkan teknologi internet dalam bentuk e-learning. Pemimpin millenial dapat melaksanakan pembelajaran dengan perkembangan fasilitas yang ada. Hal ini akan membuat proses pembelajaran di perusahaan lebih efektif dan menyenangkan bagi pesertanya. Studi yang dilakukan oleh (Afiouni, 2019) menunjukkan bahwa model pembelajaran di organisasi sudah semakin berkembang dengan berbagai macam teknologi. Salah satu teknologi yang digunakan adalah machine learning yang dapat mendukung organisasi menjadi organisasi pembelajar.

Salah satu metode pelatihan dan pengembangan adalah metode gamification. Gamification adalah memasukkan unsur-unsur dalam permainan (game) ke metode pembelajaran atau pelatihan (Erenli, 2013). Unsur-unsur dalam permaianan dikenal sebagai unsur yang menyenangkan bagi para karyawan. Unsur-unsur seperti poin, ranking, levelling, dll adalah unsur yang berguna dan dapat dimasukkan dalam metode pelatihan dan pengembangan. Proses gamfication sendiri dilakukan dengan memanfaatkan internet sebagai media penyampaian materinya. Salah satu pihak yang menyediakan pembelajaran dengan gamification adalah Kahoot.com.

Dengan demikian, MSDM memiliki banyak peran dalam mengelola pemimpin millenial. Hal utama yang perlu diperhatikan adalah bagaimana karakterisitik para pemimpin millenial untuk menjalankan fungsi manajemen sumber daya manusia. MSDM penting untuk mengelola manusia dalam mencapai tujuan perusahaan. Maka, perlu dihadirkan cara-cara baru yang lebih modern sering perkembangan zaman yang ada. Jika proses yang dilakukan masih proses zaman dahulu, maka proses ini tidak akan cocok dengan generasi millenial. Generasi millenial akan selalu memadukan teknologi dalam menjalankan fungsi sumber daya manusia. Trennya saat ini adalah bagaimana membentuk manusia di tempat kerja yang tidak asing dengan teknologi-teknologi yang baru.

\section{Kesimpulan}

Berdasarkan analisis literatur di atas, kita dapat melihat bahwa teknologi hadir dalam setiap aspek kehidupan manusia. Dalam konteks kerja, teknologi hadir untuk meningkatkan produktivias karyawan yang ada di dlaam perusahaan tersebut. Namun, perlu disadari bahwa teknologi hanya sebatas alat. Fungsi dan manfaat teknologi akan terasa jika digunakan oleh manusia yang tepat.

Dalam industri, produktivitas karyawan penting untuk keberlangsungan perusahaan. Perlu diperhatikan bagaimana memanajemen performa karyawan agar selalu 
menghasilkan kinerja yang optimal seusai bidang kerjanya masing-masing. Kinerja yang optimal akan membawa perusahaan ke keadaan yang lebih baik di masa mendatang. Dalam mengelola produktivitas, diperlukan pemimpin yang kompeten dan kredibel agar mampun menyusun sebuah sistem pengelolaan sumber daya manusia yang tepat.

Pemimpin di zaman sekarang sudah banyak berada di usia millenial. Generasi millenial adalah generasi yang lahir antara tahun 1981 - 1996. Generasi ini memiliki karakteristik yang positif maupun negatif. Generasi millenial adalah generasi yang dekat dengan teknologi, maka diperlukan sebuah sistem baru untuk gaya kepemimpinan millenial. Menurut penelitian yang dilakukan oleh Peramesti \& Kusmana, kepemimpinan millenial cenderung menunjukkan nilai-nilai kemandirian. Melalui teknologi, nilai ini dapat dikembangkan agar memberikan dampak positif bagi perusahaan. Generasi millenial memerlukan arahan dan bimbingan dari generasi sebelumnya untuk meningkatkan komitmen dan loyalitas terhadap perusahaan. Komitmen berguna untuk menjaga performa kinerja dan merasa menjadi bagian dari perusahaan tersebut. Loyalitas berarti memberikan usaha lebih daripada yang seharusnya tanpa perlu diminta apalagi dipaksa.

Generasi millenial akan selalu memanfaatkan teknologi dalam proses kerjanya. Ada banyak sekali teknologi bermunculan untuk mendukung performa dari pemimpin generasi millenial. Generasi millenial menggunakan teknologi untuk meningkatkan produktivitas sesuai dengan bidangnya masing-masing. Hal ini berguna untuk meningkatkan efisiensi waktu kerja namun tetap mendapatkan hasil yang maksimal.

Oleh karena itu, peran manajemen dalam mengembangkan generasi millenial adalah dengan memberikan ruang yang lebih pada generasi ini untuk mengembangkan potensinya. Pemimpin generasi millenial cenderung fleksibel dan tidak suka hal yang bersifat hirakis. Maka, dengan menciptakan suasana kerja yang kondusif, pemimpin millenial mampu membawa perubahan. Dalam menjalankan fungsi sumber daya manusia, pihak manajemen perlu memberikan perhatian terhadap pengembangan sektorsektor yang dipimpin oleh generasi millenial. Berikan unsur teknologi dalam kepemimpinan millenial. Pemimpin millenial mampu menggunakan teknologi tersebut dengan baik dan mendapatkan hasil yang optimal. 
Strategi Manajemen Sumber Daya Manusia dalam Mengelola Kepemimpinan Millenial Untuk Meningkatkan Produktivitas Karyawan yang Didukung oleh Teknologi Modern

\section{Bibliography}

Afiouni, R. (2019). Organizational Learning in the Rise of Machine Learning.

Al-Saqqa, S., Al-Sayyed, R., Al Shraideh, M., Obaidah, M. A., \& Balawi, S. (2014). How Technology Affects Our Life: The Case of Mobile Free Minutes in Jordan. Life Science Journal, 11(7), 1111-1127.

Au-Yong-Oliveira, M., Gonçalves, R., Martins, J., \& Branco, F. (2018). The social impact of technology on millennials and consequences for higher education and leadership. Telematics and Informatics, 35(4), 954-963.

Borman, W. C., Ilgen, D. R., \& Klimoski, R. J. (2003). Handbook of psychology: Industrial and organizational psychology, Vol. 12. John Wiley \& Sons Inc.

Cameron, K. S., \& Spreitzer, G. M. (2011). The Oxford handbook of positive organizational scholarship. Oxford University Press.

Carson, J. B., Tesluk, P. E., \& Marrone, J. A. (2007). Shared leadership in teams: An investigation of antecedent conditions and performance. Academy of Management Journal, 50(5), 1217-1234.

Cherif, F. (2020). The role of human resource management practices and employee job satisfaction in predicting organizational commitment in Saudi Arabian banking sector. International Journal of Sociology and Social Policy.

De Cenzo, D. A., \& Robbins, S. P. (1996). Human resource management.. John Wiley\& Sons. New York. USA.

Do, N. T. H., Van Nguyen, P., \& Dinh, P. U. (2018). A Qualitative Study Regarding the Leadership Traits and Styles of the Millennial Generation in the Manufacturing Industry. International Journal of Engineering \& Technology, 7(3), 52-58.

Erenli, K. (2013). The impact of gamification-recommending education scenarios. International Journal of Emerging Technologies in Learning (IJET), 8(2013).

Grotkamp, L., Schaumann, J. M., \& Riehm, P. (n.d.). MILLENNIAL LEADERS'DISPLAY OF GENERATIONAL COHORT STEREOTYPES: A QUALITATIVE RESEARCH APPROACH. Journal of Leadership in Organizations, 2(2).

Jacobs, F. R., Chase, R. B., \& Aquilano, N. J. (2004). Operations management for competitive advantage. Boston: Mc-Graw Hill, 64, 70.

Kumar, V., Kumar, U., \& Persaud, A. (1999). Building technological capability through importing technology: the case of Indonesian manufacturing industry. The Journal 
of Technology Transfer, 24(1), 81-96.

Li-Hua, R. (2009). Technology Management.

Masuda, A. D., Poelmans, S. A. Y., Allen, T. D., Spector, P. E., Lapierre, L. M., Cooper, C. L., Abarca, N., Brough, P., Ferreiro, P., \& Fraile, G. (2012). Flexible work arrangements availability and their relationship with work-to-family conflict, job satisfaction, and turnover intentions: A comparison of three country clusters. Applied Psychology, 61(1), 1-29.

McCleskey, J. A. (2018). Millennial leadership expectations, shared leadership, and the future of organizations. J Manage Sci Bus Intell, 3(2), 50-52.

Novitria, F. (2020). STUDI LITERATUR MENGENAI KARAKTERISTIK KEPEMIMPINAN DALAM LINGKUP INDUSTRI DAN ORGANISASI DI ERA GENERASI MILENIAL. Prosiding Seminar Nasional LP3M, 2.

Oswal, N., Khaleeli, M., \& Alarmoti, A. (2020). RECRUITMENT IN THE ERA OF INDUSTRY 4.0: USE OF ARTIFICIAL INTELLIGENCE IN RECRUITMENT AND ITS IMPACT. PalArch's Journal of Archaeology of Egypt/Egyptology, 17(8), 39-47.

Peña-Solórzano, C. A., Albrecht, D. W., Paganin, D. M., Harris, P. C., Hall, C. J., Bassed, R. B., \& Dimmock, M. R. (2019). Development of a simple numerical model for trabecular bone structures. Medical Physics, 46(4), 1766-1776.

Prasarti, S., \& Prakoso, E. T. (2020). KARAKTER DAN PERILAKU MILINEAL: PELUANG ATAU ANCAMAN BONUS DEMOGRAFI. Consilia: Jurnal Ilmiah Bimbingan Dan Konseling, 3(1), 10-22.

PWC. (2016). Industry 4.0: Perusahaan di Seluruh Dunia Menanamkan Investasi Sebesar \$US900 Miliar per Tahun hingga tahun 2020. Https://Www.Pwc.Com/Id/En/Media-Centre/PressRelease/2016/Indonesian/Industry-4-0--Perusahaan-Di-Seluruh-DuniaMenanamkan-Investasi-s.Html.

Robbins, S. P., Judge, T. A., \& Millett, B. (2015). OB: the essentials. Pearson Higher Education AU.

Rojko, A. (2017). Industry 4.0 concept: Background and overview. International Journal of Interactive Mobile Technologies, 11(5).

Sakurai, K., \& Jex, S. M. (2012). Coworker incivility and incivility targets' work effort and counterproductive work behaviors: The moderating role of supervisor social support. Journal of Occupational Health Psychology, 17(2), 150.

Saputra, F. S., Pamungkas, A. Y. M., Faisal, S. D., \& Rakhmawati, N. A. (2019). Pentingnya Memahami Etika dalam Mengambil dan Mengolah Data. Jurnal 
Strategi Manajemen Sumber Daya Manusia dalam Mengelola Kepemimpinan Millenial Untuk Meningkatkan Produktivitas Karyawan yang Didukung oleh Teknologi Modern

Komunikasi Profesional, 3(1).

Schuler, R. S., Dowling, P. J., \& De Cieri, H. (1993). An integrative framework of strategic international human resource management. Journal of Management, 19(2), 419-459.

Silva, R., Dutra, J., Veloso, E. F. R., \& Trevisan, L. (2020). Leadership and performance of Millennial generation in Brazilian companies. Management Research: Journal of the Iberoamerican Academy of Management.

Snyder, C. R., \& Lopez, S. J. (2001). Handbook of positive psychology. Oxford university press.

Suyanto, U. Y., Purwanti, I., \& Sayyid, M. (2019). TRANSFORMATIONAL LEADERSHIP: MILLENNIAL LEADERSHIP STYLE IN INDUSTRY 4.0. Manajemen Bisnis, 9(1).

Tedja, F. W. (2020). People First.

Volti, R. (2009). The Encyclopedia of the Age of the Industrial Revolution, 1700-1920. Technology and Culture, 50(3), 689-690.

WANASIDA, A. S., BERNARTO, I., SUDIBJO, N., \& PRAMONO, R. (2021). Millennial transformational leadership on organizational performance in Indonesia fishery startup. The Journal of Asian Finance, Economics, and Business, 8(2), 555562.

Winston, B. E., \& Patterson, K. (2006). An integrative definition of leadership. International Journal of Leadership Studies, 1(2), 6-66.

Youssef-Morgan, C. M., \& Luthans, F. (2013). Psychological capital theory: Toward a positive holistic model. In Advances in positive organizational psychology. Emerald Group Publishing Limited.

Zed, M. (2004). Metode Penelitian Kepustakaan, Yayasan Obor Indonesia. Jakarta. 